\title{
Canines vaccinated against visceral leishmaniasis develop a serological response to the Leishmania braziliensis antigen
}

\author{
Cães vacinados para leishmaniose visceral respondem \\ sorologicamente aos antigenos de Leishmania braziliensis
}

\author{
Julia de Assis Pinheiro; ; Silas Garcia Giori ${ }^{2}$; Sayanne Luns Hatum de Almeida ${ }^{1}$; \\ Rafael Assis de Souza ${ }^{1}$; Ana Paula Madureira ${ }^{3}$; Marcos Santos Zanini ${ }^{*}$
}

\begin{abstract}
American cutaneous leishmaniasis (ACL) is a zoonosis caused by Leishmania, a protozoan. Common antigens occur in the strains found in America, which allow antigenic cross-reactivity. Therefore, multivalent vaccines can be used for this pathogen. In this study, we investigated the efficacy of two different commercial vaccines for visceral leishmaniasis to induce an immune response to the soluble $L$. (Viannia) braziliensis antigens. In 2014, 70 seronegative dogs from the municipality of Iúna (Espírito Santo State, Brazil) were vaccinated and serologically evaluated by ELISA and immunoblotting by using the soluble antigen of L. braziliensis. Of the 121 dogs initially selected, only 70 received vaccination because 51 dogs tested positive by ELISA, yielding a positive frequency of $42.14 \%$ in the asymptomatic group. These 70 dogs were divided into two equal groups and administered three doses of each vaccine, according to the manufacturers' instructions. We found that the sera of dogs immunized with three doses of both vaccines A and B had antibodies against the soluble antigens of $L$. (V.) braziliensis, as determined by ELISA and immunoblotting 120 days post vaccination. Antibodies produced in response to vaccines $A$ and $B$ were found in 22/35 and 18/35 serum samples, respectively, at T1 (120 days), while $7 / 35$ and $4 / 35$ serum samples tested positive at T2 (240 days). Furthermore, immunoblotting allowed us to differentiate between vaccinated and asymptomatic dogs.
\end{abstract}

Key words: American cutaneous leishmaniasis. Leishmania vaccines. Diagnosis. ELISA. Immunoblotting.

\section{Resumo}

A Leishmaniose Tegumentar Americana (LTA) é uma zoonose causada por protozoários do gênero Leishmania. Existem antígenos comuns entre as várias espécies de Leishmania da América determinando reações antigênicas cruzadas o que possibilita vacinas multivalentes. Este estudo avaliou soros de cães vacinados com duas vacinas comerciais diferentes para leishmaniose visceral na indução de resposta imunitária cruzada para antígenos solúveis de Leishmania (Viannia) braziliensis. Durante o ano de 2014, 70 cães soronegativos para Leishmania spp. do município de Iúna (Espírito Santo, Brasil) foram vacinados e examinados sorologicamente por ELISA e imunoblotting utilizando o antígeno solúvel de $L$. braziliensis. Para 121 cães inicialmente selecionados, apenas 70 foram submetidos a vacinação porque

\footnotetext{
${ }_{1}^{1}$ Discentes de Mestrado, Universidade Federal do Espírito Santo, CCA, UFES, Alegre, ES, Brasil. E-mail: juliaassis1@hotmail. com; sayhatum@gmail.com; rafael2012agronomia@yahoo.com.br

2 Discente, CCA, UFES, Alegre, ES, Brasil. E-mail: silasveterinario@hotmail.com

3 Prof ${ }^{a}$, Universidade Federal de São João Del-Rei, Departamento de Engenharia de Biossistemas, São João del-Rei, MG, Brasil. E-mail: apmadureira@ufsj.edu.br

${ }^{4}$ Prof., CCA, UFES, Alegre, ES, Brasil. E-mail: marcos.zanini@ufes.br

* Author for correspondence
} 
51 dos animais foram positivos no teste sorológico ELISA para LTA, indicando uma frequência positiva de $42,14 \%$ para os animais LTA assintomáticos. Estes setenta animais foram divididos em dois grupos de tamanhos iguais e foram aplicadas três doses de cada vacina segundo recomendações dos fabricantes. Como resultado inédito verificamos que os soros de cães imunizados com as três doses de vacinas A e B apresentaram anticorpos contra antígenos solúveis de $L$. (V.) braziliensis quando avaliados por ELISA e immunoblotting com 120 dias pós-vacinação. As vacinas A e B apresentaram resultados positivos com presença de anticorpos nos testes serológicos, respectivamente, 22/35 e 18/35 positivos em T1 (120 dias), enquanto que em T2 (240 dias), 7/35 e 4/35 soros positivos. Além disso, o immunoblotting permitiu diferenciar o soro de cães de diferentes vacinas e cães assintomáticos.

Palavras-chave: Leishmaniose tegumentar. Vacinas Leishmania. Diagnóstico. ELISA. Imunoblotting.

\section{Introduction}

Leishmaniasis is a disease caused by the protozoans of the genus Leishmania. Depending on the virulence factors of the parasite and the immune response developed by the host, this disease is characterized by skin lesions or general visceral symptoms. This protozoan is traditionally transmitted by the bite of an infected phlebotomine sandfly, which causes various forms of clinical leishmaniasis. The visceral form of leishmaniasis is mainly caused by Leishmania chagasi/infantum (VL - visceral leishmaniasis). In Brazil, the disease exists countrywide, in both cutaneous and visceral forms. In subtropical America, the cutaneous form is known as ACL (REITHINGER; DAVIES 1999).

It is a widespread zoonotic disease and is considered an emerging and reemerging health problem in more than 15 countries (GRIMALDI; TESH 1993). Currently, the southern region of the State of Espírito Santo in Brazil is endemic for the ACL caused by L. (Viannia) braziliensis, with many cases occurring in both humans and dogs in the last decade. Several studies have suggested that the domestic dog (Canis familiaris) might play the role of a reservoir in the domestic transmission of ACL caused by L. braziliensis to humans (FALQUETO et al., 2003; MARZOCHI; MARZOCHI. 1994; MADEIRA et al., 2003). Many questions are still unanswered, regarding the role of dogs in the cycle of disease transmission, with the dogs being considered an accidental host (REITHINGER; DAVIES 1999). Polymerase chain reaction (PCR)based amplification of a prepronociceptin (PNOC) gene fragment present in the blood meal sources of the sand flies occurring in the leishmaniasisendemic areas and subsequent DNA sequencing showed that $1(3.7 \%)$ of these flies had fed on a horse (Equus caballus), 16 (59.3\%) on pigs (Sus scrofa), and $10(37 \%)$ on dogs (Canis lupus familiaris). This indicated that the transmission cycle of leishmaniasis depends on the movement of the potential animal reservoirs from the forest to the domestic households as well as from humans and domestic animals to the forest (BAUM et al., 2015). Using mathematical models, which were fitted to the data on the proportion of positive results as a function of dog age was estimated a basic reproductive number $(\mathrm{R} 0 \pm$ S.E.; $1.22 \pm$ 0.09 ), which indicated that the disease is endemic in dogs. Nevertheless, this information by itself is insufficient to incriminate dogs as ACL reservoirs, given the inability to detect parasites (or their DNA) in seropositive dogs and the previously reported failures to experimentally infect vectors feeding on dogs carrying ACL parasites (CALZADA et al., 2015).

Studies on leishmaniasis vaccines have been undertaken in the last few years because the cellmediated immunological mechanisms that can control the infection were understood. This species present a genetic homology of antigens; therefore, the use of pan-Leishmania vaccines have been suggested (HANDMAN, 2001; CARVALHO et al., 2002; MENDONÇA et al., 2016). It is mandatory to screen serological tests before vaccinating dogs against leishmaniasis to avoid vaccinating sick or 
asymptomatic animals, as a thorough evaluation of the infection in these animals is necessary to decide the course of action to be followed according to the recommendations of the sanitary surveillance system and the instructions of the manufacturers.

Previous findings indicate that indirect ELISA and immunoblotting have high sensitivity for detecting L. (V.) braziliensis infections and are considered a valuable tool for screening and diagnosing this disease, given that the association of two or more indirect methods helps increase the sensitivity of diagnosis (RIBEIRO et al., 2007; SZARGIKI et al., 2009; ZANINI et al., 2010). Conventionally, diagnostic serological tests such as enzyme-linked immunosorbent assay (ELISA) and indirect immunofluorescence assay (IFA) have a sensitivity of $91.8 \%$ and $90.8 \%$ and a specificity of $83.4 \%$ and $53.4 \%$, respectively (ARRUDA et al., 2016).

Currently, vaccine antigens have been studied in dogs, because the development of vaccines against canine leishmaniasis can form a prophylactic barrier, although the antibody response detected by standard diagnostic techniques cannot distinguish between vaccinated and naturally infected dogs (MARCONDES et al., 2013). In 2009, the Ministry of Agriculture, Livestock, and Food Supply of Brazil (MAPA) (Clarification Note 03/05/2009) issued a provisional license allowing two private laboratories to produce and trade vaccines against visceral leishmaniasis in dogs. According to the manufacturers, 21 days after the third dose, the animals should be protected. These vaccines have been administered across countries to protect against VL, independent of ACL. The protection measures related to ACL are not specified in the technical reports and documents issued by the manufacturers, although they do acknowledge the cross-protection observed between different species of Leishmania (FALQUETO et al., 2003; REIS et al., 2009).

Considering the above-detailed factors, we investigated the serological response to the two VL vaccines with respect to the production of antibodies against the L. braziliensis antigen, by using ELISA and immunoblotting during the recommended period of protection extended by the vaccines.

\section{Materials and Methods}

\section{Characterization of the study population}

This study was carried out in Iúna Municipality of the State of Espírito Santo, Brazil, an ACL-endemic region. This state has a population of approximately 26,000 and an average elevation of $661 \mathrm{~m}$. It is about occupies $460 \mathrm{~km}^{2}$ and has an average temperature of $7-30^{\circ} \mathrm{C}$, with a tropical climate, and Atlantic Forest as its characteristic vegetation. It is situated in the southern region of the state (Caparaó Region) and is bordered by the municipalities Muniz Freire in the east, Ibitirama in the south, Irupi and Ibatiba in the north, and the State of Minas Gerais in the west according to the data of Prefeitura Municipal de Iúna, 2011.

To select dogs for this study, five ACL-endemic districts from the municipality, which had reported dog and human infections, were considered. The animals were characterized as mongrels (Canis lupus familiaris), over one year of age, and living within 1000 meters from a site where there were registered cases of ACL in humans. With consent from the guardian of the dogs, 121 dogs clinically negative for ACL were selected and subjected to serological testing. All animals were electronically identified through numerical chips. Serum samples were used to determine the presence of antibodies against Leishmania species by using ELISA and immunoblotting.

Calculation of $n$ sampling was based on the canine population figures provided by the Health Surveillance for the municipality of Iúna-ES by using the formula for finite populations. The 70 vaccinated dogs were divided into two groups: 35 animals (24 males, 11 females) formed group 1 (G1) that were vaccinated with vaccine A [a purified glycoprotein fraction of $L$. donavani called fucose mannose-ligand (FML)] and 35 animals (21 males, 
14 females) formed group 2 (G2) for vaccination with vaccine B (A2 recombinant protein of $L$. donovani and saponin).

The vaccination protocol followed the manufacturers' guidelines, which recommend that the first dose should be followed by two more doses at 21-day intervals. Serum samples of the dogs were evaluated in three stages to detect antibodies only against the $L$. braziliensis antigen: $\mathrm{T}_{0}$ - before the first dose; $\mathrm{T}_{1}-120$ days after the second dose; and $\mathrm{T}_{2}-240$ days after the third dose. These blood samples were collected by venipuncture, transferred to test tubes without anticoagulant, kept at room temperature $\left(25^{\circ} \mathrm{C}\right)$ until clot retraction, and then centrifuged at $1500 \mathrm{rpm}$ for $10 \mathrm{~min}$ to separate the serum; this was maintained at $-80^{\circ} \mathrm{C}$ until further analysis.

\section{Enzyme linked immunosorbent assay (ELISA)}

The soluble fractions obtained from the promastigote forms of $L$. (V.) braziliensis (MHOM/ $\mathrm{BR} / 75 / \mathrm{M} 2903$ ) and $L$. (L.) infantum (MHOM/ $\mathrm{BR} / 1974 / \mathrm{PP} 75)$ were used to screen the serum samples of 121 dogs by ELISA to identify any reaction to Leishmania antigens. Ribeiro et al. (2007) had reported the detection of IgG antibodies against Leishmania species by a modified indirect ELISA method. Briefly, ELISA, performed in triplicate, involved fixing the antigen on the wells of 96-well polystyrene plates (concentration, $1.1 \mathrm{mg} \mathrm{mL}^{-1}$; diluted in carbonate-bicarbonate buffer, $\mathrm{pH}$ 9.6) for $12 \mathrm{~h}$ at $4^{\circ} \mathrm{C}$. Then, the wells were washed with the washing solution [sodium chloride $(\mathrm{NaCl} ; 9 \mathrm{~g})$, Tween $20(0.5 \mathrm{~mL})$, and distilled water $(1000 \mathrm{~mL})]$. After the fixing step, a blocking step was performed to avoid non-specific reactions, by adding $100 \mu \mathrm{L}$ of the blocking solution to each well. The blocking solution contained $616 \mu \mathrm{L}$ of fetal bovine serum (FBS), $10 \mathrm{~mL}$ of phosphate-buffered saline [PBS$1 \mathrm{X}$; sodium chloride $(\mathrm{NaCl} ; 8 \mathrm{~g})$, potassium chloride $(\mathrm{KCl} ; 0.2 \mathrm{~g})$, dibasic sodium phosphate $\left(\mathrm{Na}_{2} \mathrm{HPO}_{4}\right.$; $1.44 \mathrm{~g})$, monobasic potassium phosphate $\left(\mathrm{KH}_{2} \mathrm{PO}_{4}\right.$;
$0.24 \mathrm{~g})$, and distilled water $(1000 \mathrm{~mL})]$, and required an incubation period of $45 \mathrm{~min}$ at $37^{\circ} \mathrm{C}$. Then, 100 $\mu \mathrm{L}$ of the serum sample was added to each well, diluted 1:40 in PBS-T [solution of PBS 1X (1000 $\mathrm{mL})$ and Tween $20(0.5 \mathrm{~mL})]$. After $45 \mathrm{~min}$ of incubation at $37^{\circ} \mathrm{C}$, the plate was washed four times with the washing solution, and $100 \mu \mathrm{L}$ of conjugated dog anti-IgG peroxidase (sheep anti-dog total IgG HRP-conjugated/A40-121P; Bethyl Laboratory Inc., Montgomery, TX) diluted to 1:5000 in PBS-T was added to each well. Again, after incubating for $45 \mathrm{~min}$ at $37^{\circ} \mathrm{C}$, the plate was washed four times. Approximately $100 \mu \mathrm{L}$ of a solution containing 2 $\mu \mathrm{L}$ of $30 \%$ dihydrogen peroxide $\left(\mathrm{H}_{2} \mathrm{O}_{2}\right)$ and $1 \mathrm{mg}$ of ortho-phenylenediamine dihydrochloride (OPD/ Sigma ${ }^{\circledR}$ ) in $10 \mathrm{~mL}$ of phosphate citrate buffer [citric acid $\left(\mathrm{C}_{6} \mathrm{H}_{8} \mathrm{O}_{7} ; 5.19 \mathrm{~g}\right)$, dibasic sodium phosphate $\left(\mathrm{Na}_{2} \mathrm{HPO}_{4} ; 7.19 \mathrm{~g}\right)$, and distilled water $\left.(1000 \mathrm{~mL})\right]$, $\mathrm{pH}$ 5.0, was added to each well, and the plate was further incubated for $10 \mathrm{~min}$ at $37^{\circ} \mathrm{C}$. The reaction was interrupted after $10 \mathrm{~min}$, by adding $32 \mu \mathrm{L}$ of $2.5 \mathrm{M}$ $\mathrm{H}_{2} \mathrm{SO}_{4}$ to each well; the plate was read immediately at $490 \mathrm{~nm}$ by using a spectrophotometer (Multiskan Go; Thermo Scientific, Vantaa, Finland).

Determination of reactivity was based on the readings above the cut-off point (cut-off), which was calculated as the average optical density of the serum samples obtained from five negative and five positive control dogs plus twice the standard deviation of the optical density of these sera.

\section{Immunoblotting analysis}

For immunoblotting, a peroxidase-conjugated secondary anti-total IgG was used to differentiate the antibody panel of vaccinated and positive control dogs in the presence of the antigens of $L$. (V.) braziliensis. Immunoblotting analysis was performed according to the method described by Zanini et al. (2010) with minor modifications. Briefly, $10 \mu \mathrm{g}$ of the soluble antigens of $L$. braziliensis (one in each lane) and SDS-PAGE Molecular Weight Standards (Biorad Laboratories; 
Catalog number: 161-0304) were separated by sodium dodecyl sulfate- $12 \%$ polyacrylamide gel electrophoresis using a mini gel apparatus. Polypeptides from the gels were electroblotted onto 0.45 - $\mu \mathrm{m}$-thick nitrocellulose membranes by using a semidry blotter at $200 \mathrm{~mA}$ for $1.5 \mathrm{~h}$ (Biorad, USA), following the supplier's instructions.

For immunodetection, strips were cut from previously blotted membranes and blocked for 90 min with 5\% skimmed milk in PBS. Strips were then washed with PBS-T (three times, 10 min each), followed by incubation with the serum sample diluted 1:100 in PBS-T for $12 \mathrm{~h}$ at $4^{\circ} \mathrm{C}$. After incubation with the primary antibodies, the strips were washed four times, as described, and incubated for $1 \mathrm{~h}$ with peroxidase-conjugated secondary anti-total IgG canine immunoglobulins (Bethyl Laboratories, Inc., Montgomery, TX, USA) diluted in PBS-T at concentrations of 1:1000, 1:500, and 1:1000, respectively, for $1 \mathrm{~h}$ at room temperature. After the strips were washed three times with PBS-T, color development was allowed by adding $0.6 \mathrm{mg} \mathrm{mL}^{-1}$ 4-chloro-1-naphthol (Sigma $\left.{ }^{\circledR}\right)$ prepared in $0.15 \mathrm{M}$ PBS, pH 7.3, along with $0.02 \% \mathrm{H}_{2} \mathrm{O}_{2}$. The final reaction was stopped by washing the strips with distilled $\mathrm{H}_{2} \mathrm{O}$.

\section{Statistical analysis}

Data were statistically analyzed by using the $\kappa$-squared test of a variable or a $2 \times 2$ contingency table. All analyses were performed using SPSS ${ }^{\circledR}$ (version 13.0 for Windows) at a level of significance of 0.05 .

\section{Ethics}

All procedures involving experimental animals were conducted according to the Brazilian regulations and the guidelines issued by the Colégio Brasileiro de Experimentação Animal (COBEA). The project was approved by the Ethical Committee for Animal Research, Universidade Federal do Espírito Santo (CEUA-UFES), Protocol 006/2009.

\section{Results}

Only 70 of the originally selected 121 dogs were chosen for vaccination because they tested positive by ELISA.

\section{ELISA}

At zero time, the vaccinated dogs tested seronegative on ELISA, while 51 asymptomatic dogs and serum-positive controls tested ELISA positive for ACL (Table 1). Serum samples of some asymptomatic dogs showed borderline results (ELISA) but they were not chosen for vaccination.

Table 1. Number of dogs that tested positive for Leishmania infantum and L. braziliensis from the groups vaccinated with vaccines $A$ and $B$.

\begin{tabular}{ccccccccccc}
\hline \multirow{2}{*}{ districts of Íuna-ES } & \multicolumn{3}{c}{ Selection } & \multicolumn{3}{c}{ Vaccine $\mathrm{A}$} & \multicolumn{3}{c}{ Vaccine B } & Total \\
\cline { 2 - 10 } & $\mathrm{TS}$ & $\mathrm{T}_{0}$ & $\mathrm{TV}$ & $\mathrm{T}_{1}$ & $\mathrm{~T}_{2}$ & $\mathrm{TV}$ & $\mathrm{T}_{1}$ & $\mathrm{~T}_{2}$ & Vaccinated \\
\hline São João do Príncipe & 23 & 8 & 7 & 5 & 1 & 7 & 6 & 1 & 14 \\
Serrinha & 25 & 12 & 7 & 6 & 2 & 7 & 3 & 1 & 14 \\
Figueira & 20 & 6 & 7 & 4 & 1 & 7 & 4 & - & 14 \\
Tinguaciba & 23 & 8 & 7 & 3 & 2 & 7 & 2 & 1 & 14 \\
Trindade & 30 & 16 & 7 & 4 & 1 & 7 & 3 & 1 & 14 \\
\hline Total & 121 & 51 & 35 & 22 & 7 & 35 & 18 & 4 & 70 \\
\hline
\end{tabular}

TS, Total selected dogs; T0, Positive animals excluded from vaccination; TV, Total vaccinated dogs; T1, Positive animals 120 days post-vaccination; T2, Positive animals 240 days post-vaccination. 
During the post-vaccination period, after three doses of vaccines A and B, respectively, 22 and 18 were positive at $\mathrm{T}_{1}$ (120 days $-62.85 \%$ and $51.42 \%$ ), while at $\mathrm{T}_{2}$ (240 days $-20 \%$ and $11.42 \%$ ), seven and four samples tested on ELISA and were confirmed by immunoblotting using the soluble antigen of $L$. braziliensis. It was observed that for the trademark
$\mathrm{A}\left(\chi^{2}=7.76 ; \mathrm{p}=0.005\right)$ as well as for the trademark $\mathrm{B}\left(\chi^{2}=8.91 ; \mathrm{p}=0.003\right)$, there was a statistically significant difference (Figure 1) in the number of reactive animals showing a decrease between the two evaluated time points.

Figure 1. Post-vaccination period, after three doses of vaccines A and B Positive results on ELISA were confirmed by immunoblotting using the soluble antigen of Leishmania braziliensis.

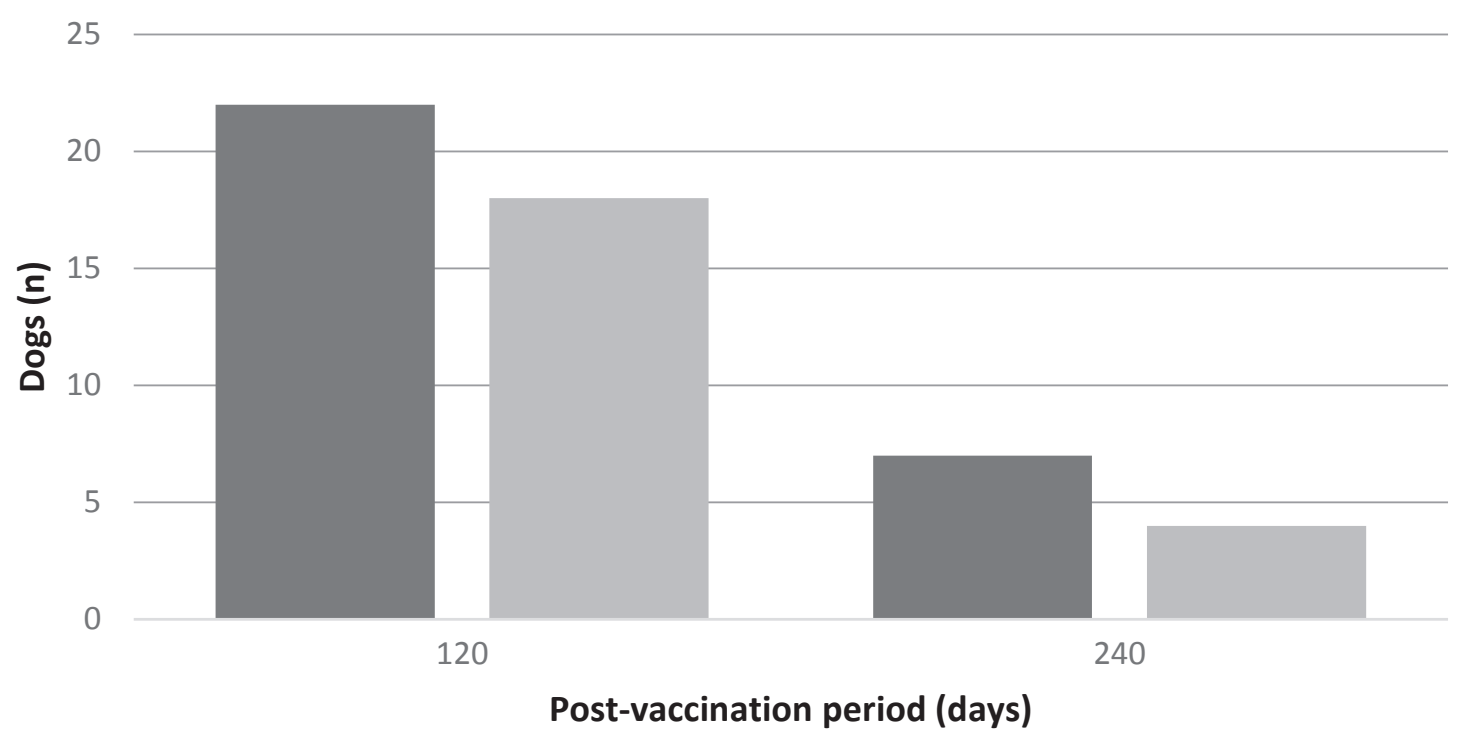

Vaccine A Vaccine B

To verify the association between the findings of ELISA and the vaccine trademark, a chi-square test using a $2 \times 2$ contingency table was performed. It was observed that there was no association between a positive ELISA test and the different trademark vaccines at 120 days $\left(\chi^{2}=0.40 ; p=0.527\right)$ as well as 240 days $\left(\chi^{2}=0.818 ; \mathrm{p}=0.366\right)$. This result was corroborated by a representative chi-square test, which showed no significant difference in the number of positive ELISA tests for the two trademark vaccines at 120 days $\left(\chi^{2}=0.61 ; \mathrm{p}=\right.$ $0.435)$ or 240 days $\left(\chi^{2}=0.82 ; p=0.37\right)$. Thus, the two vaccines behave in the same way at different evaluation time points, with respect to ELISA test findings.

\section{Immunoblotting analysis}

Immunoblotting showed differences in the reactivity of the serum samples of symptomatic and vaccinated animals toward $L$. (V.) braziliensis total $\mathrm{IgG}$ antibodies. However, a similar number of proteins were detected using antigenic panels. The five positive control sera showed many soluble protein profiles on SDS-PAGE; bands immunoreactive to $L$. (V.) braziliensis, with a relative 
MWr value ranging from 17 to $150 \mathrm{kDa}(17,21,27$, $32,45,50,54,58,66,80,97,110$, and $150 \mathrm{kDa}$ ), were observed after incubation with secondary anti-total $\mathrm{IgG}$ canine immunoglobulins. The serum samples from asymptomatic dogs predominantly contained proteins over $54 \mathrm{kDa}(54,66$, and 97 $\mathrm{kDa})$. On the other hand, the serum samples of animals immunized with vaccine A contained proteins ranging from 27 to $97 \mathrm{kDa}(27,32,50,66$, and $97 \mathrm{kDa}$ ), while those of animals immunized with vaccine $\mathrm{B}$ contained proteins of approximately $50 \mathrm{kDa}(45,50$, and $54 \mathrm{kDa})$.

\section{Discussion}

Of the initially selected 121 dogs, only 70 received vaccination because 51 of these animals tested positive for the serological ACL test based on ELISA, yielding a positive frequency of $42.14 \%$ for the asymptomatic ACL animals (Table 1). It is important to direct attention to the high number of dogs that were serologically positive, but asymptomatic. According to Arraes et al. (2008), Zanini et al. (2010), and Lakhal et al. (2012), asymptomatic animals are often observed in endemic areas and can be detected by serological methods such as ELISA, immunoblotting, and IFI. Sera from asymptomatic dogs (subclinical and self-healing forms) often test positive for $>54-\mathrm{kDa}$ protein (ZANINI et al. 2010). These results clearly indicate the need for a rigorous screening protocol to select suitable animals for vaccination in endemic regions. It is worth noting that the official test for $\mathrm{LV}$, DPP ${ }^{\circledR}$ (Dual Path Platform - CVL rapid test, BioManguinhos/Fiocruz, Rio de Janeiro, Brazil) does not detect animals positive for ACL (GRIMALDI et al., 2012). The importance of differential diagnosis in leishmaniasis and association of different tests to enhance detection sensitivity has been demonstrated previously (RIBEIRO et al., 2007; SZARGIKI et al., 2009; ZANINI et al., 2010).

This study is different from previous reports in that it evaluated the serological response to the tested vaccines by using a soluble antigen of $L$. braziliensis. Nevertheless, other authors using different antigens found similar results by ELISA. In this study, ELISA showed that $62.85 \%$ dogs immunized with vaccine A tested positive for the soluble antigen of L. braziliensis at 120 days after the third dose. This finding is in agreement with the observations of Marcondes et al. (2013), who, after evaluating the same vaccine for 180 days after the third dose, reported that $88.8 \%$ tested positive on an "in house" ELISA, $33.3 \%$ on IFAT, $11.1 \%$ on standard ELISA, and $5.5 \%$ on DPP®. These values $(62.85 \%$ and $88.8 \%)$ indicated a significant postvaccination reaction after 180 days. Reinforcing these findings, Fernandes et al. (2014) observed positive serology for $32.5 \%$ (13/40) 11 months after the third vaccination. Meanwhile, Ribeiro et al. (2015) using L. major-like antigen to assess 71 dogs vaccinated with Vaccine A and found that only one presented with positive results in the ELISA/L. major-like and IFAT assays. For Vaccine B (A2, a recombinant protein of $L$. donovani), we found that $51.42 \%$ tested positive at $\mathrm{T} 1$ and $11.42 \%$ at $\mathrm{T} 2$, by ELISA using the soluble antigen of $L$. braziliensis; however, A2 gene sequences ( $L$. donovani) were not detected in the genome of L. braziliensis (GHEDIN et al., 1997). However, anti-A2 antibodies were detected in $60 \%$ of the patients from the state of Minas Gerais (Brazil) with mucosal leishmaniasis, which is mainly caused by L. braziliensis (CARVALHO et al., 2002). On the other hand, Fernandes et al. (2014), who used an L. infantum antigen, found that $30.9 \%$ (13/42) tested positive on ELISA 280 days after the third vaccination. Our statistical results indicate that both vaccines have similar outcomes when tested by ELISA at different time points, and that from 120 to 240 days post vaccination, a significant drop was noted in the number of positive tests.

Studies on leishmaniasis vaccines have been undertaken in the last few years because the cell-mediated immunological mechanisms that can control the infection were understood. 
Leishmania species presents a genetic homology ranging from $69 \%$ to $90 \%$. Therefore, the use of heterologous antigens for the immunodiagnosis of VL and vaccination using pan-Leishmania vaccines have been recommended (HANDMAN, 2001; CARVALHO et al., 2002). Recently, this was confirmed using the LBSap vaccine (MENDONÇA et al., 2016), a vaccine containing $60 \mu \mathrm{g}$ of L. braziliensis antigen and $50 \mu \mathrm{g}$ saponin/ dose displayed immunological and parasitological profiles similar to other commercially available anti-CVL vaccines, namely, Leish-Tec ${ }^{\circledR}$ (Hertape S.A., Juatuba, Brazil), and Leishmune ${ }^{\circledR}$ (Zoetis, Campinas, Brazil). An efficacy analysis using real-time PCR showed a reduction in the extent of parasitism in the spleen (Leishmune ${ }^{\circledR}$ : $64 \%$; LBSap: $42 \%$; and Leish-Tec $\AA: 36 \%$ ) and liver (Leishmune $\AA: ~ 71 \%$; LBSap: 62\%; and Leish-Tec $®$ : $48 \%)$.

Few studies have reported immunoblotting analysis (PALATNIK-DE-SOUSA et al., 2008; TESTASICCA et al., 2014) of the vaccines. SDSPAGE analysis of FML, a species antigen of $L$. donovani (Vaccine A), showed major glycoprotein components with approximate molecular sizes corresponding to $9,28,39,43$ to 45,58 to 64 , 68 , and 92 to $95 \mathrm{kDa}$ (PALATNIK-DE-SOUSA et al., 2008). Some cross-reactions between these glycoproteins of $L$. donovani and the antigenic components of L. braziliensis justify the identical nature of the profiles obtained by immunoblotting and ELISA. Evaluation of vaccine B was performed by immunoblotting with the recombinant A2 protein; Testasicca et al. (2014) found a recombinant $52-\mathrm{kDa}$ protein in the sera of vaccinated animals, but not $L$. braziliensis antigens. Positive serological reactions for ELISA were observed by Fernandes et al. (2014) for an antigen of L. infantum when the dogs remained $30.9 \%$ reactive within six months of the first dose of Vaccine B, whereas Porrozzi et al. (2007) detected specific anti-rA2 antibodies in only one of nine L. braziliensis-infected dogs.
Thus, our findings as well as previous findings indicate the existence of some cross-reactivity between the antigens of L. infantum, L. braziliensis, and the components of Vaccine B.

It must also be considered that the antibody titer detected by ELISA at 240 days after vaccination might actually represent the extent of protection exerted against $L$. braziliensis infection.

Dogs vaccinated with the two different commercial vaccines were found to be serologically positive according to ACL ELISA, primarily after 120 and 240 days of vaccination. This study disagreed with the information supplied by the two vaccine manufacturers that vaccinated dogs are immunized, but do not develop serological response after 21 days of the third dose (by routine ELISA). Thus, it is essential that dogs vaccinated with the tested vaccines be strictly registered to ensure that they are not identified as asymptomatic, yet positive for leishmaniasis, in future.

\section{Financial Support}

Fundação de Amparo à Pesquisa e Inovação do Espírito Santo- FAPES and Coordenação de Aperfeiçoamento de Pessoal de Nível Superior CAPES, Brasil

\section{References}

ARRAES, S. M. A. A.; MARINI, M. T.; MARTELLO, D.; SILVEIRA, T. G. V.; LONARDONI, M. V. C.; NANNI, M. R. Investigação sorológica de casos subclínicos de leishmaniose tegumentar após um surto em uma localidade endêmica. Revista da Sociedade Brasileira de Medicina Tropical, Uberaba, v. 41, n. 2, p. 205-208, 2008.

ARRUDA, M. M.; FIGUEIREDO, F. B.; MARCELINO, A. P.; BARBOSA, J. R.; WERNECK, G. L.; NORONHA, E. F.; ROMERO, G. A. Sensitivity and specificity of parallel or serial serological testing for detection of canine Leishmania infection. Memórias do Instituto Oswaldo Cruz, Rio de Janeiro, v. 111, n. 3, p. 168-173, 2016. 
BAUM, M.; CASTRO, E. A. de; PINTO, M. C.; GOULART, T. M.; KLISIOWICZ, D. R.; VIEIRA DA COSTA-RIBEIRO, M. C. Molecular detection of the blood meal source of sand flies (Diptera: Psychodidae) in a transmission area of American cutaneous leishmaniasis, Paraná State, Brazil. Acta Tropica, Amsterdam, v. 143, n. 3, p. 8-12; 2015.

CALZADA, J. E.; SALDAÑA, A.; GONZÁLEZ, K.; RIGG, C.; SANTAMARIA, A. M.; RODRIGUEZ, I.; GOTTDENKER, N. L.; LAURENTI, M. D.; CHAVES, L. F. Cutaneous role Leishmaniasis in dogs: is high seroprevalence indicative of a reservoir. Parasitology, Cambridge, v. 142, n. 9, p. 1202-1214, 2015.

CARVAlHO, F. A.; CHAREST, H.; TAVARES, C. A.; MATLASHEWSKI, G.; VALENTE, E. P.; RABELLO, A.; GAZZINELLI, R. T.; FERNANDES, A. P. Diagnosis of American visceral leishmaniasis in humans and dogs using the recombinant Leishmania donovani A2 antigen. Diagnostic Microbiology and Infectious Disease, Amsterdam, v. 43, n. 4, p. 289-295, 2002.

FALQUETO, A.; SESSA, P. A.; FERREIRA, A. L.; VIEIRA, V. P.; SANTOS, C. B.; VAREJÃO, J. B. M.; CUPOLILLO, E.; PORROZZI, R.; CARVALHO-PAES, L. E.; GRIMALDI JUNIOR, G. Epidemiological and clinical features of Leishmania (Viannia) braziliensis american cutaneous and mucocutaneous leishmaniasis in the state of Espírito Santo, Brazil. Memórias do Instituto Oswaldo Cruz, Rio de Janeiro, v. 98, n. 8, p. 1003-1010, 2003.

FERNANDES, C. B.; JUNIOR, J. T. M.; JESUS, C.; SOUZA, B. M.; LARANJEIRA, D. F.; FRAGA, D. B.; TAVARES-VERAS, P. S.; BARROUIN-MELO, S. M. Comparison of two commercial vaccines against visceral leishmaniasis in dogs from endemic areas: $\mathrm{IgG}$, and subclasses, parasitism, and parasite transmission by xenodiagnosis. Vaccine, Amsterdam, v. 32, n. 11, p. 1287-1295, 2014.

GHEDIN, E.; ZHANG, W. W.; CHAREST, H.; SUNDAR, S.; KENNEY, R. T.; MATLASHEWSKI, G. Antibody response against a Leishmania donovani amastigote-stage-specific protein in patients with visceral leishmaniasis. Clinical and Diagnostic Laboratory Immunology, Los Angeles, v. 4, n. 5, p. 530-535, 1997.

GRIMALDI, G.; TESH, R. B. Leishmaniases of the New World: Current Concepts and Implications for Future Research. Clinical Microbiology Reviews, Washington, v. 6, n. 3, p. 230-250, 1993.

GRIMALDI, G.; TEVA, A.; FERRREIRA, A. L.; SANTOS, C. B. dos.; PINTO, I. D.; AZEVEDO, C. T. de.; FALQUETO, A. Evaluation of a novel chromatographic immunoassay based on Dual-Path Platform technology (DPP ${ }^{\circ}$ CVL rapid test) for the serodiagnosis of canine visceral leishmaniasis. Transactions of the Royal Society of Tropical Medicine and Hygiene, Oxford, v. 106, n. 1, p. 54-59, 2012.

HANDMAN, E. Leishmaniasis: current status of vaccine development. Clinical Microbiology Reviews, Washington, v. 14, n. 2, p. 229-243, 2001.

LAKHAL, S.; MEKKI, S.; BEN-ABDA, I.; MOUSLI, M.; AMRI, F.; AOUN, K.; BOURATBINE, A. Evaluation of an enzyme-linked immunosorbent assay based on crude Leishmania histone proteins for serodiagnosis of human infantile visceral leishmaniasis. Clinical and Vaccine Immunology, Washington, v. 19, n. 9, p. 14871491, 2012.

MADEIRA, M. D. F.; UCHÔA, C. M. A.; LEAL, C. A.; SILVA, R. M. M.; DUARTE, R.; MAGAlHÃES, C. M.; SERRA, C. M. B. Leishmania (Viannia) braziliensis em cães naturalmente infectados. Revista da Sociedade Brasileira de Medicina Tropical, Uberaba, v. 36, n. 5, p. 551-555, 2003.

MARCONDES, M.; LIMA, V. M. F.; ARAÚJO, M. D. F. L.; HIRAMOTO, R. M.; TOLEZANO, J. E.; VIEIRA, R. F.; BIONDO, A. W. Longitudinal analysis of serological tests officially adopted by the Brazilian Ministry of Health for the diagnosis of canine visceral leishmaniasis in dogs vaccinated with Leishmune $\mathbb{R}$. Veterinary Parasitology, Amsterdam, v. 197, n. 3, p. 649-652, 2013.

MARZOCHI, M. C. A.; MARZOCHI, K. B. F. Tegumentary and visceral leishmaniasis in Brazil emerging anthropozoonosis and possibilities for their control. Caderno de Saúde Pública, Rio de Janeiro, v. 10, n. 2, p. 359-375, 1994.

MENDONÇA, L. Z. de; RESENDE, L. A.; LANNA, M.F.; AGUIAR-SOARES, R. D.; ROATT, B. M.; CASTRO, R. A.; BATISTA, M. A.; SILVEIRA-LEMOS, D.; GOMES, J. de A.; FUJIWARA, R. T.; REZENDE, S. A.; MARTINS-FILHO, O. A.; CORRÊA-OLIVEIRA, R.; DUTRA, W.O.; REIS, A. B.; GIUNCHETTI, R. C. Multicomponent LBSap vaccine displays immunological and parasitological profiles similar to those of Leish-Tec $\AA$ and Leishmune ${ }^{\circledR}$ vaccines against visceral leishmaniasis. Parasites \& Vectors, London, v. 9, n. 1, p. 472-484, 2016.

PALATNIK-DE-SOUSA, C. B; BARBOSA, A. F.; OLIVEIRA, S. M.; NICO, D.; BERNARDO, R. R.; SANTOS, W. R.; RODRIGUES, M. M.; SOARES, I.; BORJA-CABRERA, G. P. FML vaccine against canine visceral leishmaniasis: from second-generation to synthetic vaccine. Expert Review of Vaccines, Londres, v. 7, n. 6, p. 833-851, 2008. 
PORROZZI, R.; SANTOS-DA-COSTA, M. V.; TEVA, A.; FALQUETO, A.; FERREIRA, A. L.; SANTOS, C. D.; FERNANDES, A. P.; GAZZINELLI, R. T.; CAMPOS-NETO, A.; GRIMALD-JR, G. Comparative evaluation of enzyme-linked immunosorbent assays based on crude and recombinant leishmanial antigens for serodiagnosis of symptomatic and asymptomatic Leishmania infantum visceral infections in dogs. Clinical and Vaccine Immunology, Washington, v. 14, n. 5, p. 544548, 2007.

REIS, A. B.; MARTINS-FILHO, O. A.; TEIXEIRACARVALHO, A.; GIUNCHETTI, R. C.; CARNEIRO, C. M.; MAYRINK, W.; TAFURI, W. L.; CORRÊAOLIVEIRA, R. Systemic and compartmentalized immune response in canine visceral leishmaniasis. Veterinary Immunology and Immunopathology, Amsterdam, v. 12, n. 1, p. 87-95, 2009.

REITHINGER, R.; DAVIES, C. R. Is the domestic dog (Canis familiaris) a reservoir host of american cutaneous leishmaniasis? A critical review of the current evidence. The American Journal of Tropical Medicine and Hygiene, Mclean, v. 61, n. 4, p. 530-541, 1999.

RIBEIRO, F. C.; DE-O-SCHUBACH, A.; MOUTACONFORT, E.; SCHUBACH, T. M.; MADEIRA, M. F.; MARZOCHI, M. C. Use of ELISA employing Leishmania (Viannia) braziliensis and Leishmania (Leishmania) chagasi antigens for the detection of $\operatorname{IgG}$ and $\operatorname{IgG} 1$ and $\mathrm{IgG} 2$ subclasses in the diagnosis of American tegumentary leishmaniasis in dogs. Veterinary Parasitology, Amsterdam, v. 148, n. 3, p. 200-206, 2007.
RIBEIRO, R. A.; TEIXEIRA-NETO, R. G.; BELO, V. S.; FERREIRA, E. C.; SCHALLIG, H. D. F. H.; SILVA, E. S. Ability of immunodiagnostic tests to differentiate between dogs naturally infected with Leishmania infantum and Leishmune( $\left.{ }^{\circledR}\right)$-vaccinated dogs. Veterinary Research Communications, Gewerbestrasse, v. 39, n. 2, p. 87-95, 2015.

SZARGIKI, L.; CASTRO, E. A.; LUZ, E.; KOWALTHUK, W.; MACHADO, A. M.; SOCCOL, V. Comparison of serological and parasitological methods for cutaneous leishmaniasis diagnosis in the state of Paraná, Brazil. The Brazilian Journal of Infectious Diseases, Rio de Janeiro, v. 13, n. 1, p. 47-52, 2009.

TESTASICCA, M. C.; DOS-SANTOS, M. S.; MACHADO, L. M.; SERUFO, A. V.; DORO, D.; AVELAR, D.; TIBPURCIO, A. M.; ABRANTES, C. F.; MACHADO-COELHO, G. L.; GRIMALDI-JUNIOR, G.; GAZZINELLI, R. T.; FERNANDES, A. P. Antibody responses induced by Leish-Tec $\AA$, an A2-based vaccine for visceral leishmaniasis, in a heterogeneous canine population. Veterinary Parasitology, Amsterdam, v. 204, n. 3, p. 169-176, 2014.

ZANINI, M. S.; VIANA, K. F.; REIS, A. B.; CAMPOS, D. R.; MUSSI, J. M.; ZANINI, S.; LEMOS, E. M. Leishmania (Viannia) braziliensis: immunoblotting analysis for the detection of $\operatorname{IgG}$ subclasses in the diagnosis of symptomatic and asymptomatic dogs. Veterinary Parasitology, Amsterdam, v. 173, n. 1, p. 143146, 2010. 